\title{
The Challenge of Skin Lesions in Systemic Diseases
}

\section{O Desafio das Lesões Cutâneas nas Doenças Sistémicas}

Ana Isabel Lopes ${ }^{1 *}$, Isabel O. Cruz¹, Rui Môço

KEYWORDS: Erythema Nodosum; Sarcoidosis

PALAVRAS-CHAVE: Eritema Nodoso; Sarcoidose

A 47-year-old man, obese, without medical problems, presented with a 15-day history of painful erythematous nodular lesions on the anterior side of lower limbs. He had no improvement with antibiotics and non-steroidal anti-inflammatory drugs (NSAIDs). He developed migratory and symmetric arthralgias (ankles, knees, elbows) and low-grade fever. The skin lesions progressed to the upper limbs. On physical examination, a mild swelling and tenderness in both ankles was noted, and lesions suggestive of erythema nodosum were seen (Fig. 1).

Laboratory studies including a complete blood count, plasma levels of urea nitrogen, electrolytes, creatinine, calcium, liver enzymes, and urinalysis were normal, but a C-reactive protein (CRP) of $90.4 \mathrm{mg} / \mathrm{L}$ was detected. The chest $X$-ray showed bilateral para-hilar opacities and chest tomography revealed enlarged hilar and mediastinal lymph nodes (Fig. 2). Infectious causes were excluded, interferon gamma release assay test was negative and immunological study was normal, including normal level of angiotensin converting enzyme (ACE). Löfgren's syndrome/acute sarcoidosis was assumed. Due to previous NSAIDs failure, the patient began treatment with $40 \mathrm{mg} /$ day of prednisolone, with prompt resolution of the skin lesions, arthralgias and normalization of CRP. Corticosteroids were tapered to $5 \mathrm{mg}$ /day without recurrent symptoms. No other organs were affected.

Sarcoidosis is a multi-systemic granulomatous disease of unknown etiology. Polyarthritis occurs in 10\%-39\%, particularly in the early stages of the disease. ${ }^{1}$ Löfgren's syndrome is a particular type of acute sarcoidosis, char- 


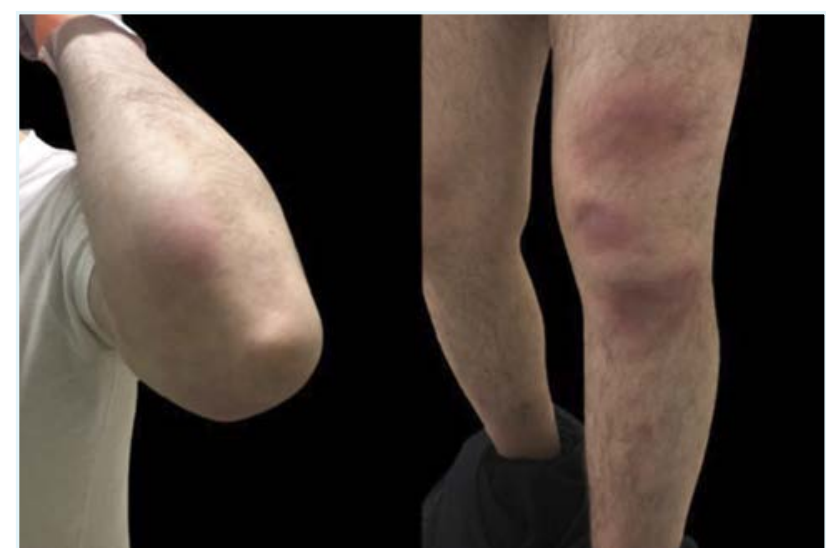

FIGURE 1. Multiple lesions suggestive of erythema nodosum in both upper (left) and lower limbs (right).

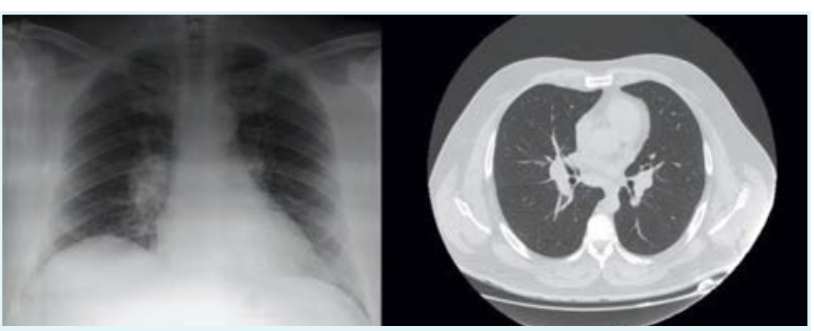

FIGURE 2. Bilateral para-hilar opacities on chest X-ray (left). The chest tomography (right) showing enlarged hilar and mediastinal lymph nodes.

acterized by symmetrical polyarthritis, hilar adenopathy and erythema nodosum. 1,2 This triad has a 95\% diagnostic specificity for sarcoidosis, and biopsy is not mandatory. ${ }^{3}$ However, it is essential to exclude other diagnoses, namely infectious causes such as tuberculosis, paraneoplastic syndromes, inflammatory bowel disease and drugs. ${ }^{4,5}$

Löfgren's syndrome represents less than $10 \%$ of sarcoidosis cases and it is usually self-limited. Treatment involves corticosteroids in severe cases. ${ }^{4}$ High levels of ACE are associated with persistent arthritis, not observed in our patient. ${ }^{3}$

\section{RESPONSABILIDADESÉTICAS}

CONFLITOS DE INTERESSE: Os autores declaram a inexistência de conflitos de interesse na realização do presente trabalho.

FONTES DE FINANCIAMENTO: Não existiram fontes externas de financiamento para a realização deste artigo.

CONFIDENCIALIDADE DOS DADOS: Os autores declaram ter seguido os protocolos da sua instituição acerca da publicação dos dados de doentes.

CONSENTIMENTO: Consentimento do doente para publicação obtido.
PROVENIÊNCIA E REVISÃO POR PARES: Não comissionado; revisão externa por pares.

\section{ETHICAL DISCLOSURES}

CONFLICTS OF INTEREST: The authors have no conflicts of interest to declare.

FINANCING SUPPORT: This work has not received any contribution, grant or scholarship.

CONFIDENTIALITY OF DATA: The authors declare that they have followed the protocols of their work center on the publication of data from patients.

PATIENT CONSENT: Consent for publication was obtained.

PROVENANCE AND PEER REVIEW: Not commissioned; externally peer reviewed.

\section{REFERENCES}

1. Byun CW, Yang SN, Yoon JS, Kim SH. Lofgren's syndrome-acute onset sarcoidosis and polyarthralgia: a case report. Ann Rehabil Med. 2013; 37:295-9. doi:10.5535/arm.2013.37.2.295.

2. Ungprasert P, Ryu JH, Matteson EL. Clinical Manifestations, Diagnosis, and Treatment of Sarcoidosis. Mayo Clin Proc Innov Qual Outcomes. 2019;3:358-75. doi:10.1016/j.mayocpiqo.2019.04.006.

3. O'Regan A, Berman JS. Sarcoidosis. Ann Intern Med. 2012; 156: ITC5-ITC16. doi:10.7326/0003-4819-156-9-20120501001005.

4. Chowaniec M, Starba A, Wiland P. Erythema nodosum - review of the literature. Reumatologia. 2016;54:79-82. doi:10.5114/ reum.2016.60217.

5. Blake T, Manahan M, Rodins K. Erythema nodosum - a review of an uncommon panniculitis. Dermatol Online J. 2014;20: 22376. 